\title{
Pengaruh Promosi dan Distribusi Terhadap Kepuasan Pelanggan Pada PT Tiga Serangkai Internasional Cabang Bandung.
}

\author{
Anang Martoyo ${ }^{1}$. Fajar Mahardika \\ 1,2 Institut Teknologi dan Bisnis Bank Rakyat Indonesia (BRI Institute)
}

\begin{abstract}
The objectives of the research are to know the responses about promotion, distribution, customer satisfaction, and customer trust, also to analyze the influence of promotion and distribution to customer satisfaction and its implication on customer trust. The population in this study is PT. Tiga Serangkai International in the reater Bandung Region. The research method used in this research is descriptive and verification research method with a sample size of 90 respondents, data collection by interview using a questionnaire, observation and literature. Sampling technique using the "Disproportionate Starfied Random Sampling" method. Data analysis method used is path analysis. The results showed that promotion and distribution simultaneously influence customer satisfaction, partially promotion and distribution have a significant effect on customer satisfaction. Promotion gives an influence on customer satisfaction by $16 \%$, while distribution gives an effect of $75.9 \%$. The contribution of promotion and distribution variables to customer satisfaction is $73.7 \%$, the remaining $26.3 \%$ is the contribution of the variables not included in the study.
\end{abstract}

Keywords: Promotion; Distribution; Customer Satisfaction;

\section{A. PENDAHULUAN}

PT. Tiga Serangkai International cabang Bandung merupakan salah satu unit bisnis PT Tiga Serangkai International yang beroperasi di wilayah Bandung Raya, Subang dan Sumedang sejak tahun 1991. Pada tahun 2009 menempati kantor milik sendiri berkedudukan di Jl. Pasir Salam No. 23 Ancol, Regol, Kota Bandung, Jawa Barat. Perusahaan berupaya menjaga kepuasan pelanggan selama lebih dari 50 tahun dan hingga kini masih tetap eksis melayani pelanggan. Kepuasan pelanggan senantiasa diciptakan dengan tujuan untuk memberikan manfaat kepada pelanggan dan mendapatkan profit atau laba yang optimal bagi perusahaan. Sebagian besar studi memperlihatkan bahwa semakin tinggi tingkat kepuasan pelanggan, akan semakin tinggi pula kesetiaan pelanggan, dan akan membeli lagi ketika perusahaan memperkenalkan produk baru.

Pencapaian penjualan dibandingkan dengan rencana penjualan (sales plan) pada Tahun 2012, 2013, 2014, 2015 dan 2016 ditampilkan pada tabel di bawah ini : 
ISSN NO. (PRINT) 2598-0823, (ONLINE) 2598-2893

Tabel 1

Pencapaian Penjualan 5 tahun terakhir

\begin{tabular}{|c|c|c|c|c|c|c|}
\hline \multirow{2}{*}{ Tahun } & \multicolumn{2}{|c|}{ Plan } & \multicolumn{2}{c|}{ Actual } & \multicolumn{2}{c|}{ AR (\%) } \\
\cline { 2 - 8 } & Vol (Exp) & Value (Rp) & $\begin{array}{c}\text { Vol } \\
(\text { Exp) }\end{array}$ & Value (Rp) & Vol & Value \\
2012 & 315.33 & 11.509 .651 .200 & $\begin{array}{c}239.4 \\
26\end{array}$ & $\begin{array}{c}7.941 .408 . \\
102\end{array}$ & 76 & 69 \\
\hline 2013 & 407.172 & 13.809 .001 .300 & $\begin{array}{c}267.9 \\
54\end{array}$ & $\begin{array}{c}10.395 .17 \\
8.424\end{array}$ & 66 & 75 \\
\hline 2014 & 430.155 & 17.065 .879 .800 & $\begin{array}{c}290.6 \\
23\end{array}$ & $\begin{array}{c}10.339 .10 \\
6.425\end{array}$ & 68 & 61 \\
\hline \multirow{2}{*}{2015} & 394.293 & 13.349 .471 .385 & $\begin{array}{c}324.4 \\
36\end{array}$ & $\begin{array}{c}13.554 .29 \\
7.528\end{array}$ & 82 & 102 \\
\hline 2016 & 380.201 & 16.835 .532 .762 & $\begin{array}{c}345.8 \\
63\end{array}$ & $\begin{array}{c}14.052 .60 \\
5.936\end{array}$ & 91 & 83 \\
\hline \multirow{2}{*}{ Jml } & 1.927 .154 & 72.569 .536 .447 & $\begin{array}{c}1.468 \\
.302\end{array}$ & $\begin{array}{c}56.282 .59 \\
6.415\end{array}$ & 76 & 78 \\
\hline
\end{tabular}

Sumber : Dessus TSI BO Bandung (cut off 31 Des 2016)

Berdasarkan data di atas dapat digambarkan bahwa terjadi fluktuasi pencapaian plan, posisi pencapaian (achievement ratio) tertinggi terjadi pada tahun 2015 sebesar 102\% secara value (brutto) dan pencapaian terendah sebesar 61\% di tahun 2014 serta rata-rata pencapaian per tahunnya sebesar $78 \%$. Suatu rencana yang telah ditetapkan tetapi hasilnya tidak sesuai atau terdapat penyimpangan tujuan dari rencana tersebut, maka hal seperti itu dapat dikatakan sebagai masalah.

Pada kurun waktu 5 tahun terakhir pencapaian laba atau profit juga terjadi fluktuatif dan secara umum cenderung merugi. Tabel 3 menampilkan pencapaian laba PT. Tiga Serangkai International cabang Bandung pada tahun 2012, 2013, 2014, 2015, dan 2016 :

Tabel 3

Profit dan Loss

\begin{tabular}{|l|l|c|c|r|l|}
\hline No & Tahun & $\begin{array}{c}\text { Actual Gross } \\
\text { Profit (Rp) }\end{array}$ & $\begin{array}{c}\text { Profit Top } \\
\text { Down (Rp) }\end{array}$ & Varian (Rp) & Ket \\
\hline 1 & 2012 & 1.209 .961 .744 & 1.637 .020 .070 & $(427.058 .326)$ & Loss \\
\hline 2 & 2013 & 1.783 .050 .472 & 1.821 .529 .953 & $(38.479 .482)$ & Loss \\
\hline 3 & 2014 & 1.779 .097 .471 & 2.003 .306 .134 & $(224.208 .663)$ & Loss \\
\hline 4 & 2015 & 1.520 .194 .757 & 1.446 .584 .671 & 73.610 .087 & Profit \\
\hline 5 & 2016 & 1.853 .770 .293 & 1.866 .083 .329 & $(12.313 .036)$ & Loss \\
\hline
\end{tabular}

Sumber : Dessus TSI BO Bandung (cut off 31 Des 2016)

Berdasarkan tabel 3 di atas diketahui bahwa kerugian terbesar PT. Tiga Serangkai International cabang Bandung terjadi pada tahun 2012 sebesar Rp. 427.058.326,-- 
Keuntungan perusahaan hanya dapat dicapai pada tahun 2015 sebesar Rp. 73.610.087,sedangkan 3 tahun sebelum dan 1 tahun sesudahnya masih mengalami kerugian.

Survey pendahuluan untuk 30 responden telah dilakukan dengan hasil sebagai berikut:

Tabel 5

Prosentase Kepuasan Pelanggan

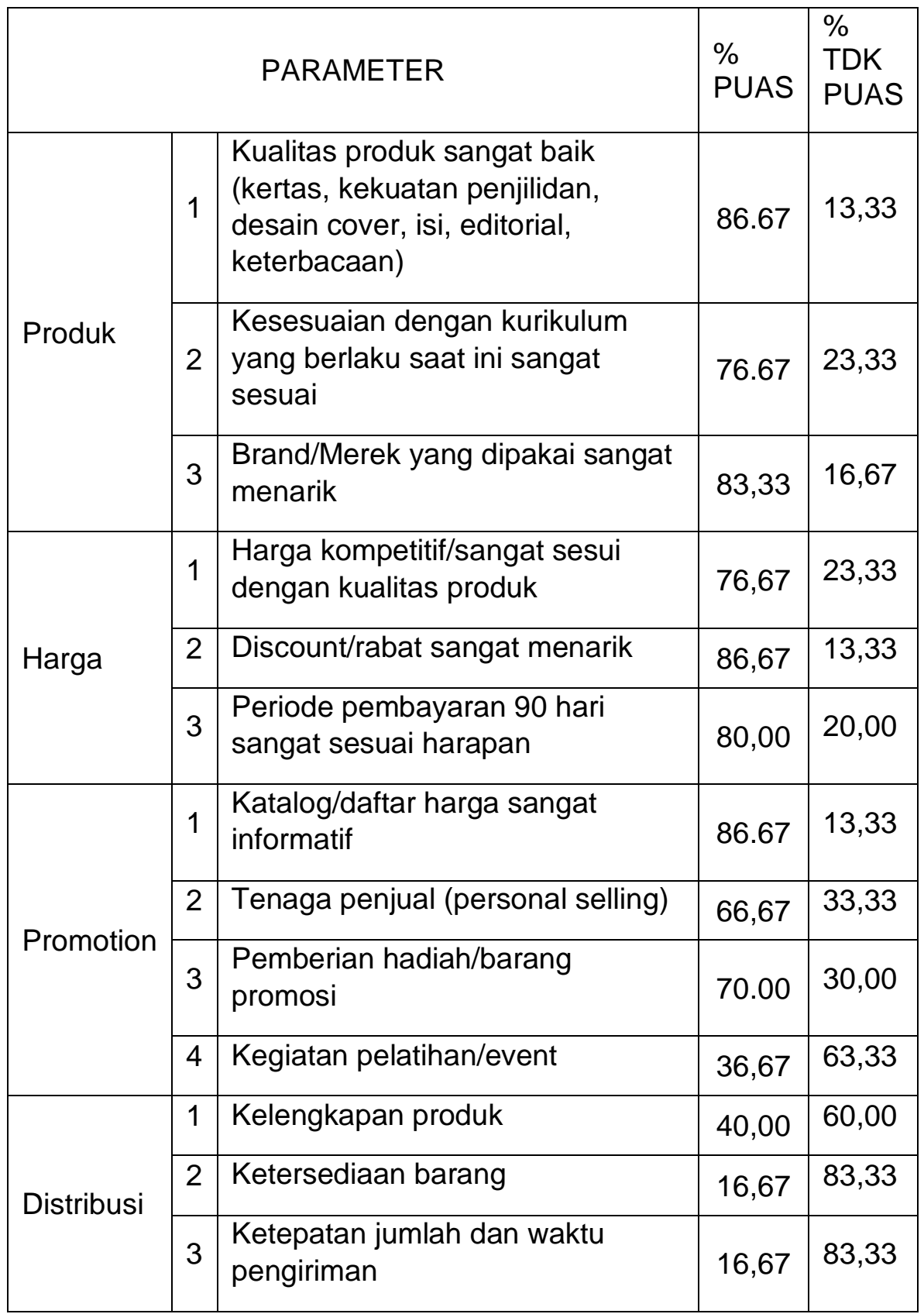

Dari tabel 5 diketahui bahwa tingkat kepuasan pelayanan petugas (personal selling) hanya $53 \%$ dan tingkat kepuasan pelanggan terhadap kinerja distribusi buku baik ketepatan jumlah maupun ketepatan waktunya hanya $27 \%$. Tingkat kepercayaan 
pelanggan terhadap produk dan layanan hanya $43 \%$, diasumsikan sebagai akibat dari menurunnya kinerja promosi dan distribusi.

\section{B. KAJIAN LITERATUR}

Diliterature review penulis melampirkan penelitian terdahulu yang berkaitan dengan penelitian penulis, yaitu sebagai berikut:

Anissa Faradina Sekolah Tinggi IImu Ekonomi Indonesia (STIESIA) Surabaya 2016 Jurnal. "Pengaruh Promosi Dan Kualitas Pelayanan Terhadap Kepuasan Pelanggan Pada Rumah Cantik Alamanda". Persamaan Hubungan promosi degan kepuasan pelanggan. Dengan hasil Promosi memiliki pengaruh terhadap kepuasan pelanggan (Faradina, A., \& Satrio, B. (2016).

A.S. Manampiring, W.J.A.F. Tumbuan.,R.S. Wenas. Jurnal EMBA Vol.4 No.2 Juni 2016, Hal. 164-176. "Analisis Produk, Harga, Lokasi, Promosi Terhadap Kepuasan Konsumen Pada Kartu Kreditpt.Bank Mandiri Tbk. Manado". Dengan persamaan Hubungan promosi dengan kepuasan pelanggan. Dengan hasil Promosi \& variabel lain secara bersama-sama berpengaruh terhadap kepuasan konsumen (Manampiring, A. S., Tumbuan, W. J., \& Wenas, R. S. (2016).

Ludfi Mariadi dan Havidz Aima 42 -56 Jurnal MIX, Volume IV,No. 1, Febuari 2014 Pascasarjana Universitas Mercu Buana. "Pengaruh Brand Equity, Persepsi Harga Dan Distribusi Terhadap Kepuasan Pelanggan Produk Pakaian Merekoldblue Company". Dengan Persamaan Hubungan antara distribusi dengan kepuasan pelanggan. Dengan hasil Ekuitas merek dan distribusi mempengaruhi kepuasan pelanggan sebesar $56,3 \%$.

Yuyus Kadarusman. Universitas Pamulang, Tangerang Selatan. 2015. "Analisis Pengaruh Saluran Distribusi Terhadap Kepuasan Pelanggan Pada PT. Indomarco Adi Prima". Dengan persamaan Hubungan antara distribusi dengan kepuasan pelanggan. Dengan hasil Saluran distribusi $(x)$ mempunyai pengaruh yang signifikan terhadap kepuasan pelanggan (y) (Kadarusman, Y. (2015).

Dona Margaretha Jurnal IImiah Mahasiswa Fakultas Ekonomi dan Bisnis Vol. 3 No. 2 2016. "Pengaruh Kualitas Produk Dan Saluran Distribusi Terhadap Loyalitas Merek Melalui Kepuasan Pelanggan (Studi Kasus Konsumen Penikmat Rokok Tambang Emas Alami Dan Coklat Alami)". Dengan persamaan Hubungan antara distribusi dengan kepuasan pelanggan. Dengan hasil Saluran distribusi berpengaruh signfikan terhadap kepuasan pelanggan (Margaretha, D. (2016).

Tonny Sopan Sofian Gultom Hariyani H. Zakaria Ismail Jurnal Ilmiah Progresif Manajemen Bisnis (JIPMB), Vo. 1, Issue 1, November 2014. "Pengaruh Merek, Saluran DistribusiTerhadap Kepuasan Pelanggan, Loyalitas Pembelian Produk Aqua (Studi Kasus Pada PT. Bintang Suryasindo Cabang Pangkalpinang Bangka)". Dengan persamaan Hubungan antara distribusi dengan kepuasan pelanggan. Dengan hasil Terdapat pengaruh yang signifikan dari Saluran Distribusi Terhadap Kepuasan Pelanggan (Gultom, T. S. S., Hariyani, H., \& Ismail, Z. (2014)).

Muhammad Asir. Pascasarjana UNHAS Pebruari - April 2011. "Pengaruh Saluran Distribusi, Kualitas Produk Dan Kebijakan Harga Terhadap Kepuasaan Pelanggan (Studi Kasus PT. Centa Brasindo Abadi)". Dengan persamaan Hubungan antara distribusi dengan kepuasan pelanggan. Dengan hasil Saluran distribusi, Kualitas produk, dan kebijakan harga berpengaruh thd kepuasan pelanggan (Asir, M. (2005)).

Paradigma penelitian dapat digambarkan dalam skema sebagai berikut: 


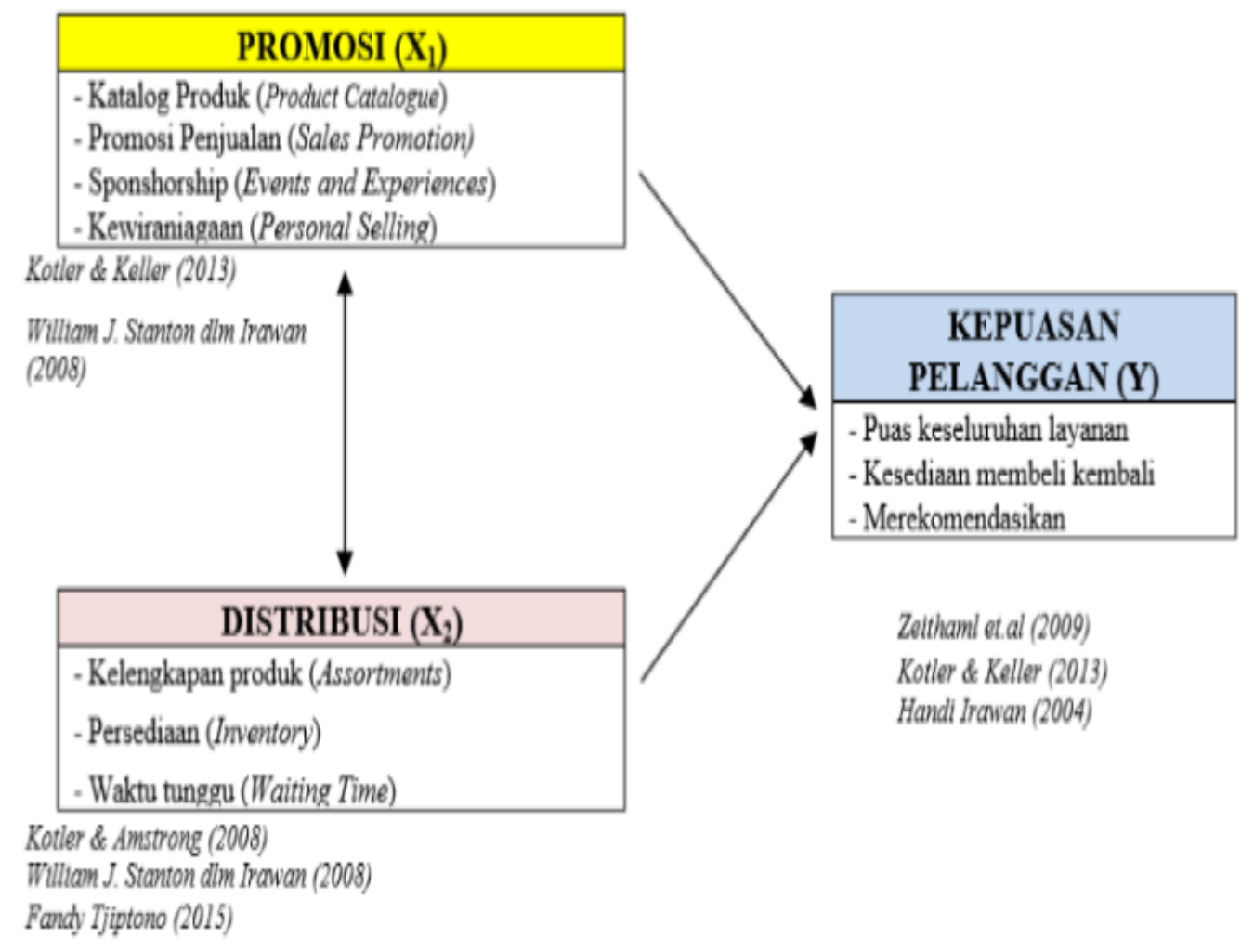

Hipotesis:

1. Promosi berpengaruh terhadap kepuasan pelanggan;

2. Distribusi berpengaruh terhadap kepuasan pelanggan;

3. Promosi dan distribusi berpengaruh terhadap kepuasan pelanggan

\section{B. METODOLOGI PENELITIAN}

Dalam penelitian ini digunakan pendekatan kuantitatif dengan metode survey. Sumber data dari penelitian ini berasal dari para pelanggan buku pelajaran PT. Tiga Serangkai International Cabang Bandung yang berjumlah sebanyak 815 pelanggan. Penelitian bersifat verifikatif, yaitu metode yang bertujuan untuk menguji secara matematis dugaan mengenai adanya hubungan antar variabel dari masalah yang sedang diselidiki di dalam hipotesis. Ketentuan-ketentuan yang digunakan dalam metode adalah sebagai berikut: 
1. Instrumen untuk pengumpulan data berbentuk non test berupa kuesioner dengan menggunakan data interval dengan skala semantic differensial, observasi, dan wawancara yang bertujuan mencari hubungan 3 (tiga) variabel dengan 10 dimensi dan 27 indikator.

2. Metode sampling yang digunakan adalah teknik 'Disproportionate Stratified Random Sampling' karena populasinya mempunyai anggota atau unsur yang tidak homogen dan berstrata secara proporsional

3. Sampel dalam penelitian ini ditentukan dengan menggunakan rumus Slovin, $\mathrm{n}=$ $\mathrm{N} / \mathrm{N}(\mathrm{d}) 2+1, \mathrm{n}=$ ukuran sampel, $\mathrm{N}=$ Populasi, $\mathrm{d}=$ taraf nyata. Hasil perhitungan rumus Slovin dengan tingkat kesalahan sebesar 0,10 adalah $n=815 / 815(0,1)^{2}+1$ $=89,07$. Jadi anggota populasi yang diambil sebagai sampel dalam penelitian ini sebanyak 90 orang

\section{HASIL DAN PEMBAHASAN}

Hasil perhitungan nilai koefisien jalur pada persamaan struktur dengan bantuan software IBM SPSS dapat diketahui pengaruh parsial promosi (X1) dan distribusi (X2) terhadap kepuasan pelanggan $(\mathrm{Y})$ ditampilkan pada tabel koefisien jalur di bawah ini :

\section{Tabel 6}

Hasil Koefisien Jalur

\begin{tabular}{|c|c|c|c|c|c|c|c|c|c|}
\hline \multicolumn{10}{|c|}{ Coefficients } \\
\hline & \multirow{2}{*}{ Model } & \multicolumn{2}{|c|}{$\begin{array}{l}\text { Unstandardized } \\
\text { Coefficients }\end{array}$} & \multirow{2}{*}{$\frac{\begin{array}{c}\text { Standardized } \\
\text { Coefficients }\end{array}}{\text { Beta }}$} & \multirow{2}{*}{$t$} & \multirow{2}{*}{ Sig. } & \multicolumn{3}{|c|}{ Correlations } \\
\hline & & B & $\begin{array}{c}\text { Std. } \\
\text { Error }\end{array}$ & & & & $\begin{array}{l}\text { Zero- } \\
\text { order }\end{array}$ & Partial & Part \\
\hline \multirow{3}{*}{1} & (Constant) & 8,978 & 2,547 & & 3,524 &, 001 & & & \\
\hline & Promosi(X1) &, 130 &, 054 &, 160 & 2,414 & 018 & .585 & .251 & 133 \\
\hline & $\begin{array}{l}\text { Distribusi } \\
(\mathrm{X} 2)\end{array}$ & 1,052 &, 092 &, 759 & 11,438 &, 000 &, 848 &, 775 &, 629 \\
\hline
\end{tabular}

Dengan melihat tabel, dapat diketahui bahwa signifikasi dari kedua variabel yaitu promosi $(X 1)=0,018$ dan distribusi $(X 2)=0,000$ lebih kecil dari 0,05. Hasil ini memberikan kesimpulan bahwa variabel promosi (X1) dan distribusi (X2) berpengaruh signifikan terhadap kepuasan pelanggan $(\mathrm{Y})$. Pada pengujian parsial diketahui besarnya pengaruh variabel promosi $(\mathrm{X} 1)$ terhadap kepuasan pelanggan $(\mathrm{Y})$ adalah $\mathrm{PYX} 1 \times \mathrm{r}$ Zero-Order $=$ $0,160 \times 0,585=0,0936$. Adapun besarnya pengaruh parsial distribusi $(X 2)$ terhadap kepuasan pelanggan adalah PYX2 $\times$ r Zero-Order $=0,759 \times 0,848=0,644$. Total pengaruh promosi dan distribusi terhadap kepuasan pelanggan adalah $0,0936+0,644=0,737$ disebut dengan koefisien determinasi (R2).

Berdasarkan pengolahan data menggunakan IBM SPSS hasil perhitungan koefisien determinasi (R2) model substruktur 1 dapat ditampilkan pada tabel 7 berikut ini: 
ISSN NO. (PRINT) 2598-0823, (ONLINE) 2598-2893

Tabel 7

Koefisien Determinasi

Model Summary

\begin{tabular}{|c|c|c|c|c|}
\hline Model & $R$ & R Square & $\begin{array}{c}\text { Adjusted } R \\
\text { Square }\end{array}$ & $\begin{array}{c}\text { Std. Error of the } \\
\text { Estimate }\end{array}$ \\
\hline 1 & $0,859^{2}$ & 0,737 & 0,731 & 3,78052 \\
\hline
\end{tabular}

a. Predictors: (Constant), Distribusi (X2), Promosi (X1)

Hasil perhitungan untuk koefisien determinasi mutiple $\left(R^{2}{ }_{\mathrm{yx} 1, y \times 2}\right)$ sebesar 0,737 , hal ini menunjukkan bahwa kontribusi atau sumbangan variabel promosi dan distribusi terhadap kepuasan pelanggan adalah sebesar 73,7\%, sisanya sebesar $26,3 \%$ merupakan kontribusi dari variabel-variabel yang tidak dimasukkan dalam penelitian. Adapun besarnya koefisien $\varepsilon_{1}$ dapat dicari dengan rumus sebagai berikut :

Nilai 0,737 adalah nilai koefisien determinasi dari hasil regresi linier $\left(R^{2}\right)$ atau $R$ Square

$$
\begin{aligned}
\varepsilon_{1} & =\sqrt{ }\left(1-R^{2}\right) \\
& =\sqrt{ } 1-0,737 \\
& =\sqrt{ } 0,264 \\
& =\mathbf{0 , 5 1 3}
\end{aligned}
$$

Sehingga diperoleh Persamaan dan diagram jalur model struktural seperti pada gambar 2 di bawah ini :

Persamaan model strukur:

$$
\begin{aligned}
& Y=P_{Y X 1 .} X_{1}+P_{Y X 2} . X_{2}+P_{Y} \cdot \varepsilon_{1} \varepsilon_{1} \\
& Y=0,160 X 1+0,759 X 2+0,513 \varepsilon_{1}
\end{aligned}
$$

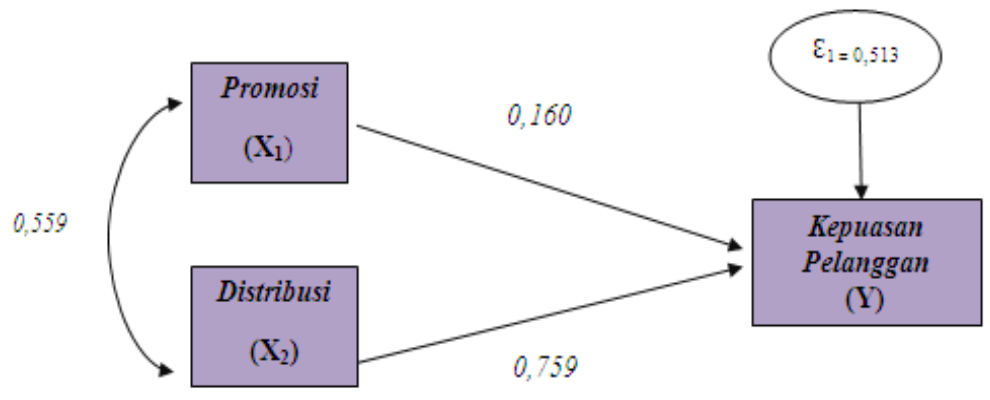

Gambar 2

Model Hubungan $X_{1}, X_{2}$ dengan $Y$ 
Penjelasan persamaan model struktur di atas adalah sebagai berikut :

- Secara parsial promosi berpengaruh terhadap kepuasan pelanggan. Besaran pengaruh parsial adalah 0,160 . Karena nilai lebih mendekati nol, maka pengaruhnya lemah.

- Secara parsial distribusi berpengaruh terhadap kepuasan pelanggan. Besaran pengaruh parsial adalah 0,759 . Karena nilai lebih mendekati 1 , maka pengaruhnya kuat.

- Besaran pengaruh variabel di luar model sebesar 0,513. Karena nilai lebih mendekati 1, maka pengaruhnya di luar model kuat.

\section{HASIL UJI HIPOTESIS SIMULTAN}

Pengujian pengaruh secara simultan (keseluruhan) antara promosi dan distribusi terhadap kepuasan pelanggan, ditampilkan dalam data uji signifikansi ANOVA dari SPSS seperti terlihat pada tabel di bawah ini:

Tabel 8

Hasil Uji F \& Signifikansi

\begin{tabular}{|l|l|c|c|c|c|c|}
\hline \multicolumn{2}{|c|}{ Model } & $\begin{array}{c}\text { Sum of } \\
\text { Squares }\end{array}$ & df & Mean Square & F & Sig. \\
\hline \multirow{3}{*}{1} & Regression & 3485,554 & 2 & 1742,777 & 121,938 &, $000^{\circ}$ \\
\cline { 2 - 8 } & Residual & 1243,435 & 87 & 14,292 & & \\
\cline { 2 - 8 } & Total & 4728,989 & 89 & & & \\
\hline
\end{tabular}
a. DependentVariable: Kepuasan Pelanggan $(\gamma)$
b. Predictors: (Constant), Distribusi (X2), Promosi (X1)

Hipotesis statistik dirumuskan sebagai berikut :

Ho : Pyx1 = Pyx2 = 0 : promosi dan distribusi secara bersama-sama tidak berpengaruh terhadap kepuasan pelanggan.

$\mathrm{Ha}: \mathrm{Pyx} 1=\mathrm{Pyx} 2 \neq 0$ : promosi dan distribusi secara bersama-sama berpengaruh terhadap kepuasan pelanggan.

Kriteria pengujian menggunakan SPSS sebagai berikut :

- Apabila sig <0,05 maka Ho ditolak

- Apabila sig > 0,05 maka Ho diterima

- penolakan $\mathrm{H}_{0}$ jika: $\mathrm{F}$ hitung $>\mathrm{F}$ tabel, Ha diterima

$\mathrm{DF} 1=3-1=2$ \& DF2 $=90-3=87$, diketahui nilai $\mathrm{F}$ tabel sebesar $: 2,709$.

- $\quad$ Pada tabel 8 nilai F hitung : 121,938 > 2,709 maka Ho ditolak Ha diterima.

- Hasil uji signifikansi pada tabel 4.57 diketahui sebesar 0,000.

Karena $0,000<0,05$ maka Ho ditolak. 
Kesimpulannya : promosi (X1) dan distribusi (X2) secara bersama-sama (simultan) berpengaruh terhadap kepuasan pelanggan $(Y)$.

Hasil pengujian hipotesis menunjukkan bahwa promosi dan distribusi secara simultan (bersama-sama) berpengaruh terhadap kepuasan pelanggan, hal ini dikatakan bahwa promosi dan distribusi pada waktu yang bersamaan mempengaruhi respon kepuasan pelanggan. Berdasarkan hasil analisis jalur, diketahui bahwa persamaan koefisien model struktural, kepuasan pelanggan adalah $0,160 \times 1+0,759 \times 2+0,513 \varepsilon 1$. Artinya distribusi memberikan pengaruh yang lebih besar terhadap kepuasan pelanggan daripada promosi. Faktor distribusi menjadi salah satu kunci keberhasilan perusahaan untuk meningkatkan penjualan dan mencapai target.

Nilai koefisien korelasi antara promosi dan distribusi sebesar 0,559 menggambarkan bahwa antara keduanya mempunyai hubungan yang linear positip. Sudah seharusnya perusahaan lebih fokus lagi dalam mengkombinasikan dua variabel ini agar bisa saling menguatkan dan bersinergis untuk meraih over target penjualan dan keuntungan. Konstribusi promosi dan distribusi terhadap kepuasan pelanggan dapat dilihat dari nilai koefisien determinasi $\left(R^{2}\right)$ sebesar 0,737 atau $73,7 \%$ sedangkan sisanya sebesar $26,3 \%$ adalah pengaruh variabel lain diluar model. Besarnya kontribusi promosi dan distribusi terhadap kepuasan pelanggan harus mendapatkan perhatian bagi perusahaan untuk dapat memenuhi harapan pelanggan.

\section{HASIL UJI HIPOTESIS PARSIAL}

Pengujian secara parsial antara promosi dan distribusi terhadap kepuasan pelanggan, dapat dilihat pada Tabel 6 "Hasil Koefisien Jalur" output dari SPSS yaitu sebagai berikut:

Prosedur pengujiannya sebagai berikut :

1. Ho : $b=0$ (Promosi dan distribusi secara parsial tidak berpengaruh terhadap kepuasan pelanggan)

2. Ha : $b \neq 0$ (Promosi dan distribusi secara parsial berpengaruh terhadap kepuasan pelanggan)

Kriteria pengujian membandingkan T hitung dengan T tabel taraf signifikansi 0,05. Uji 2 sisi jadi : 0,25 DF $=90-3=87$ diketahui $\mathrm{T}$ Tabel sebesar 1,988

- Ho ditolak jika: T hitung > T tabel,

- Ha diterima jika T hitung $<T$ tabel

Pengujian menggunakan SPSS dengan kriteria:

- Jika nilai signifikansi <0,05 maka Ho ditolak

- Jika nilai signifikansi > 0,05 maka Ho diterima

Dari tabel 6 diketahui bahwa :

- $\quad$ T hitung promosi $=2,414>1,988$ (berpengaruh)

- $\quad$ T hitung distribusi $=11,438>1,988$ (berpengaruh)

- Nilai signifkansi 0,018<0,05 (berpengaruh)

- Nilai signifkansi 0,000<0,05 (berpengaruh)

Berdasarkan signifikansi dan uji T tabel maka dapat disimpulkan bahwa:

- Promosi secara parsial berpengaruh terhadap kepuasan pelanggan.

- Distribusi secara parsial berpengaruh terhadap kepuasan pelanggan.

Jurnal Pemasaran Kompetitif, Vol. 3, No.2 / Februari 2020 
Dalam pengujian secara parsial promosi berpengaruh signifikan terhadap kepuasan pelanggan. Kegiatan promosi PT Tiga Serangkai International cabang Bandung sudah berjalan cukup baik, akan tetapi belum mampu memberikan kepuasan yang optimal kepada pelanggan. Hal-hal yang perlu untuk diperbaiki untuk meningkatkan kepuasan pelanggan adalah dengan menambah frekuensi pemberian promosi dan memperbanyk mengadakan kegiatan sponsorship berupa pelatihan/seminar/workshop untuk pelanggan.

Secara parsial promosi berpengaruh positif dan signifikan terhadap kepuasan pelanggan. Hal ini dapat dikatakan bahwa semakin baik kegiatan promosi yang dilakukan, maka akan meningkatkan kepuasan terhadap pelanggan. Pengaruh promosi terhadap kepuasan pelanggan sudah cukup baik, namun ada faktor lain yang menyebabkan pelanggan belum merasakan kepuasan karena kegiatan distribusi yang dilakukan oleh perusahaan masih mengecewakan dengan indikator berupa ketersediaan stok, ketepatan pengiriman, ketepatan pemenuhan pesanan dan indikator lainnya.

Secara parsial distribusi berpengaruh signifikan terhadap kepuasan, di mana apabila apabila terjadi perbaikan sistem distribusi maka akan mendorong peningkatan kepuasan pelanggan. Kegiatan distribusi PT Tiga Serangkai International cabang Bandung belum sesuai harapan, mengingat masih banyaknya keluhan pelanggan terkait dengan pemenuhan pesanan dan waktu pengiriman yang tidak tepat atau sering terlambat.

Besarnya pengaruh langsung distribusi terhadap kepuasan pelanggan adalah sebesar 0,759 atau $76 \%$. Artinya tinggi rendahnya kepuasan pelanggan dipengaruh oleh distribusi sebesar $76 \%$, sedangkan sisanya sebesar $24 \%$ dijelaskan faktor lain di luar model. Pengaruh distribusi terhadap kepuasan dikategorikan kuat karena mendekati satu, hal ini dapat dikatakan bahwa keberhasilan kegiatan distribusi sangat mempengaruhi kepuasan pelanggan. Beberapa dimensi dari distribusi adalah assortments, inventory, dan waiting time. Apabila perusahaan mampu menyiapkan kelengkapan produk, ketersediaan stok, dan segera melakukan pengiriman maka akan berdampak meningkatkan kepuasan pelanggan secara nyata.

Dari hasil analisis di atas, dapat dikatakan bahwa untuk meningkatkan kepuasan pelanggan maka kegiatan distribusi harus lebih diprioritaskan daripada kegiatan promosi. Pemberian promosi dalam jumlah besar berupa potongan harga, hadiah, atau bentuk promosi lainnya tidak akan menarik pelanggan jika kondisi ketersediaan stoknya tidak terjamin

\section{E. KESIMPULAN}

1. Variabel promosi secara parsial berpengaruh signifikan dan positif sebesar $16 \%$ terhadap kepuasan pelanggan;

2. Variabel distribusi berpengaruh signifikan dan positif sebesar $75,9 \%$ terhadap kepuasan pelanggan;

3. Hasil analisis jalur diketahui bahwa promosi dan distribusi secara simultan (bersama-sama) berpengaruh terhadap kepuasan pelanggan sebesar $73,7 \%$ dan sisanya sebesar $26,3 \%$ dipengaruhi oleh variabel di luar model. 


\section{Saran}

1. Perlu dilakukan penelitian lanjutan dengan variabel dan dimensi yang berbeda;

2. Pada kegiatan promosi perlu menambah frekuensi pemberian material promo dan pelatihan;

3. Pada kegiatan distribusi fisik perlu diperhatikan tentang ketepatan waktu pengiriman dan pemenuhan pesanan.

\section{DAFTAR PUSTAKA}

Faradina, A., \& Satrio, B. (2016). Pengaruh Promosi dan Kualitas Pelayanan Terhadap Kepuasan Pelanggan pada Rumah Cantik Alamanda. Jurnal IImu dan Riset Manajemen, 5(7), 1-18.

Gultom, T. S. S., Hariyani, H., \& Ismail, Z. (2014). PENGARUH MEREK, SALURAN DISTRIBUSI TERHADAP KEPUASAN PELANGGAN, LOYALITAS PEMBELIAN PRODUK AQUA (Studi Kasus Pada PT. Bintang Suryasindo Cabang Pangkalpinang Bangka). Jurnal Progresif Manajemen Bisnis, 1(1), 55-67.

Kadarusman, Y. (2015). Analisis Pengaruh Saluran Distribusi Terhadap Kepuasan Pelanggan Pada PT. Indomarco Adi Prima (Skripsi Manajemen S1, 2015).

Lesmana, R. (2016). Strategi Pemasaran Untuk Meningkatkan Penjualan Perumahan Di Green River City Bekasi (Studi Kasus Di PT. Artha Bangun Pratama). INOVASI Jurnal IImiah IImu Manajemen, 3(2), 40-59.

Lesmana, R., \& Ayu, S. D. (2019). Pengaruh Kualitas Produk Dan Citra Merek Terhadap Keputusan Pembelian Kosmetik Wardah PT Paragon Tehnology And Innovation. Jurnal Pemasaran Kompetitif, 2(3), 59-72.

Manampiring, A. S., Tumbuan, W. J., \& Wenas, R. S. (2016). Analisis Produk, Harga, Lokasi, Promosi Terhadap Kepuasan Konsumen Pada Kartu Kredit Pt. Bank Mandiri Tbk. Manado. Jurnal EMBA: Jurnal Riset Ekonomi, Manajemen, Bisnis dan Akuntansi, 4(2).

Margaretha, D. (2016). PENGARUH KUALITAS PRODUK DAN SALURAN DISTRIBUSI TERHADAP LOYALITAS MEREK MELALUI KEPUASAN PELANGGAN (Studi Kasus Konsumen Penikmat Rokok Tambang Emas Alami Dan Coklat Alami). Jurnal IImiah Mahasiswa FEB, 3(2).

Mariadi, L., \& Aima, H. (2014). Pengaruh Brand Equity, Persepsi Harga Dan Distribusi Terhadap Kepuasan Pelanggan Produk Pakaian Merek Old Blue Company. MIX: Jurnal Ilmiah Manajemen, 4(1).

Sunardi, N. S. N., Lesmana, R., \& Tumanggor, M. (2018). Implementasi Manajemen Dalam Meningkatkan Iman Dan Taqwa Masyarakat Dusun Panyeredan, Cimanggu, Cisalak, Subang-Jawa Barat. Jurnal Pengabdian Dharma Laksana, 1(1). 